DOI https://doi.org/10.18551/rjoas.2018-02.09

\title{
WHETHER BOOK TAX DIFFERENCES AFFECT THE PRICE BOOK VALUE?
}

\author{
Ranatarisza Mirza Maulinarhadi \\ Taxation Program, Bussines Department, Faculty of Administrative Science, Universitas \\ Brawijaya, Indonesia \\ E-mail: mirza mr.fia@ub.ac.id
}

\begin{abstract}
The objective of the study was to describe book tax different influence towards price book value. The study was an explanatory study with quantitative approach. The setting of the study was manufacturing companies listed in Indonesian Stock Exchange. The independent variables were book tax different which measured using temporary differences and book tax different measured by permanent differences. The dependent variable was price book value. The data analysis involved descriptive statistics, classical assumption test, multiple linear regression and hypothesis-testing using Statistical Package for Social Science 21.0. The findings were: temporary differences did not have significant influence towards price book value, meaning that increasing temporary differences would result in insignificant increase in price book value and was not the main determining factor of price book value; permanent differences had significant influence towards price book value, which mean increasing permanent differences would increase price book value and was the main determining factor in describing level of company's price book value; there was significant, positive and simultaneous influence between temporary differences and permanent differences as the indicator of book tax different towards price book value in the companies.
\end{abstract}

\section{KEY WORDS}

Book tax differences, permanent differences, temporary differences, price book value.

Business entity operations are run by multiple parties that have different interests. Some parties have quite dominant role such as management, which based on the agency theories is referred to as agents and shareholders is called principal; each has an important role for company's operations. Managers are the ones who physically run company's operations and shareholders establish policies that management carry out. Managers and shareholders are separated by control functions and ownership functions. It is possible that such separation causes conflicts of interest between agents and principals which may affect management of company in terms of availability of information about company performance, recorded in its financial statements.

The concept of agency theory explains that the different interest between agent (management) and principal (owner) causes an assymerty information about company performance. Company performance can be described through financial statements prepared in each accounting period. The financial report is one of the media used by the principal (owner) to obtain information related to investment decisions. Information from financial statements generated by the company is also used as a basis for determining corporate income tax, in which is calculated based on fiscal net profit as the basis for calculation multiplied by applicable tax rate. The fiscal net profit is derived from reconciliation of the income statement of the company, in which the revenues and expenses of the company are adjusted to the applicable taxation rules into revenues and expenses which may be recognized and may be charged only as calculated. It may result in book tax differences between commercial profit and fiscal net profit due to differences in recognition and accounting principles. Book-tax differences represent differenct amount of commercial profit based on financial reporting standart with fiscal net profit obtaine in tax regulations (Hanlon, 2005). Management of company prepares financial statements, in each accounting period with two different objectives, to fulfill the obligation to make financial reporting by International Financial Reporting Standart (IFRS) and to fulfill the tax obligations. 
Management undertakes fiscal reconciliation and makes adjustments to the reporting that have been made in accorandce with the IFRS, in accorandce to tax law and regulations. Eventually, it allows distinction between commercial profit and fiscal profit; the difference arises because of the differences principle and the basis of recognition between commercial accounting and taxation accounting.

In the context of taxation accounting, Book Tax Differences can be divided into permanent differences and temporary differences. Temporary differences, according to Tang (2012), represent difference in the time of recognition of income or expenses between taxes and accounting resulting in higher accounting profits than tax profits or otherwise in an accounting period, in which the difference is temporary. On the other hand, permanent differences or fixed differences represent a form of accounting treatment whereby items are included in one measure of commercial profit, but not included in size of fiscal profit, due to the different definitions of those items from the two basic rules of reporting namely IFRS and tax regulations.

It is in line with the finding of Hanlon (2005)'s research results that book tax differences are separated into temporary differences and permanent differences providing information about the current profit quality. Hanlon's (2005) study investigating role of temporary differences in book tax differences indicates that firms with large and positive book tax differences have lower earnings persistence than ones with smaller book tax differences. This is also in line with some financial analysis literatures which state that increased profit reported by management caused by the selection of accounting methods in the accrual process will lead to a significant difference between accounting profit and fiscal profit.

Users of accounting information created by companies rely heavily on numbers presented in published financial statements. Investors will be more interested if company is able to maintain profits from year to year because there is tendency that such company remains stable. Investor's response is reflected in stock price that represents market response and is one indicator of company's value. Market response represented by company's stock price can be compared to book value per share in order to create a stable value in looking at the value of the company. It can be concluded that investors's interest towards company can be represented by stock price compared to book value of the company or its price book value (PBV).

PBV is used to measure stock price performance against its book value. The larger the PBV ratio is, the higher company value is according to investors compared to the funds invested by the company. In general, companies that run well is ones of which PBV ratio reaches above one that indicates that the stock market value is greater than the book value. This study will examine the effect of book tax different on the price book value of manufacturing companies listed in Indonesian Stock Exchange as the national capital market authority. Companies listed in the Indonesian Stock Exchange are called emiten. They have obligation to issue annual financial statements that can be used by investors to determine investment decisions. Companies listed in Indonesian Stock Exchange are divided into three types: main sectors, manufacturing, and services.

One type of company listed on the Indonesia Stock Exchange is manufacturing industry. Manufacturing companies listed in Indonesian Stock Exchange are divided into several sectors, namely basic and chemical industries, various industry and consumer goods industry. Based on the data compiled from the Ministry of Industry, in 2015 the manufacturing industry has high growth. The growth of the industry achieved $5.21 \%$. The percentage is higher than the 2015 economic growth rate of only $4.73 \%$. The national manufacturing industry has the largest contribution to the national economics compared to the other sectors.

The dominance of the manufacturing industry is also illustrated by the total industrial product exports between January and August 2015 of USD72.21 billion. The number contributed $70.44 \%$ to the total national exports of USD102.52 billion. The high growth of the manufacturing industry is dominated by the consumer goods industry sector, which consists of chemical, pharmaceutical and traditional medicine industries, tobacco processing industries and food industries (The Ministry of Industry, 2015). Based on the elaboration, the 
researcher is interested to conduct research describing whether or not book-tax difference has influence towards price book value. The statements of the problems are 1) does temporary difference affect price book value?; 2) does permanent difference affect price book value?; and 3) do temporary differences and permanent differences, both are book-tax difference indicator, simultaneously influence price book value?. The goals of this research are to: 1) describe influence of temporary differences towards price book value, 2) describe influence of permanent difference towards price book value, and 3) describe simultaneous influence of temporary differences and permanent difference as book-tax difference indicator towards price book value.

\section{LITERATURE REVIEW}

Agency Theory. Agency theory is the theory that underlies company's business practices. The theory is combination between economic theory, decision theory, sociology, and organizational theory (Bamberg, 1989). The main principle of this theory states the existence of agency relationships in the company's business practices. The agency relationship, according to Jensen (1976), is a contract between management (agent) and shareholders (principal) to achieve the common goal that is increasing value of a company through increased shareholder wealth.

Separation of maganement function and ownership function is the beginning of the agency theory. The agency theory is emphasized to overcome two problems that can occur in agency relationship (Einsenhard as cited in Deviana, 2010), namely: (1) agency problem arising when desire or objective of the principal and agent is at the opposite and it is difficult for the principal to verify what the agent actually does; (2) risk-sharing issues that arise when the principal and agent have different attitudes toward risk. Different views that arise between the agent and principal cause assymerty information.

The asymmetry information between management and owners provides opportunity for managers to act opportunistically, that is to gain personal gain; in terms of financial reporting, managers can earn earnings management to ultimately provide the best possible picture of the company's performance. The contrary is also done for tax purposes; the manager will minimize the amount of profit listed in the income statement so as not to be subject to greater taxes.

Book-tax differences. Book-tax differences are difference between amount of profit calculated based on accounting and profit calculated in accorandce to tax regulations (Hanlon, 2005). Each year the company's management prepares financial statements with two different objectives, namely to meet IFRS requirement and tax regulations. This difference arises because of the principle difference between commercial accounting and taxation accounting.

The purpose of financial statements based on financial accounting standards is to provide information regarding financial position, performance, and changes in a financial position in the framework of decision making (Zain, 2007). Financial position information is primarily provided in the balance sheet while performance information is primarily provided in the income statement and the information on changes in financial position is presented in the statement of cash flows. The purpose of financial reporting under the tax law basically has similarity that is to determine the results of business operations with the measurement and recognition of income and expenses. According to Zain (2007) the provisions of tax laws and regulations are not merely a resource channeling instrument, but are often used for the purpose of influencing taxpayer behavior for investment, welfare and others that are sometimes used as justification for deviations from tax accounting principles.

The difference in principle or treatment between commercial accounting and taxation accounting leads to two types of income, accounting income and fiscal income. Accounting profit/ loss is net income for one period minus any tax expense. The fiscal profit/ loss or taxable income is profit or loss during one period which is calculated based on taxation regulations with due attention to fiscal correction. Fiscal correction is an advanced process of the commercial accounting cycle, making adjustments to income and expenses, where only 
income classified as income tax objects and deductible expenses alone may be taken into account in the income statement. This taxable income is the basis for calculating the income tax payable in the current tax year.

The tax regulations in Indonesia require that the fiscal profit be calculated based on the accounting method on which accounting profit is based. The method of accounting used is the accrual method, so the company does not need to do double bookkeeping for the two purposes of reporting the profit. This is because at the end of each year the company is required to conduct fiscal reconstruction to determine the amount of fiscal profit by making adjustments to accounting profit based on tax regulations. Although between accounting income and taxable income are prepared on the accrual basis, the final result of the calculation is not the same (Hanlon, 2005).

Different profit is derived from different income and incurred fee by commercial accounting and taxation accounting as follow (Saputro, 2011):

a. Income which is recognized as accounting but not recognized as income according to taxation. This type of income is subject to final tax which has been regulated in the 2008 Decree number 36 Article 4 Paragraph (2) Income Tax. The types of taxable income are final, namely bank interest, income from prizes, and gain from sale of investment in stock exchange, in addition to dividend income from limited liability company (LLC) having shares in other LLCs of $25 \%$ or more being regulated in the Income Tax Decree Article 4 paragraph (3).

b. Income which is not recognized as profit by accounting but recognized as income according to taxation. Examples of these types of income are grants or donations related to business, employment and ownership.

c. Costs recognized as deductions in accounting income but are not recognized as deductions in taxable profit as stated in the Income Tax Decree Article 9 paragraph (1). Examples of these costs include costs that should not be deducted from gross income, such as providing benefits to employees related to recreational purposes and others.

In taxation accounting context, book tax differences is divided into permanent differences and temporary differences.

Temporary Differences refer to different time to recognize income or fee between taxation and accounting and therefore, accounting profit is higher than tax profit or vice-versa in one period (Tang, 2012). Temporary Differences can be seen based on discrepancy between number of recorded assets or liabilities and incurred tax. Temporary Differences occur due to different purpose between accounting and tax (Jackson, 2009).

In commercial accounting, revenues are recognized when earned and costs are recognized as incurred, or accrual basic. The Common Accepted Accounting Principle gives management freedom to choose its accounting procedures. Managers can choose among several different accounting methods. The options are for example, in selecting depreciation method and estimation of despreciation and amortization period. Managers are also free to use their judgment to determine which funding reserves may reduce profits, such as the determination of reserves for bad debts, compensation reserves, warranty reserves, and so on (Mills as cited in Wijayanti, 2006).

In taxation accounting, firms can only recognize received revenue and expenses incurred in the period concerned. Revenue is recorded when cash is received, unearned earnings can not be included in the fiscal profit, and expenses are recognized when the cash is issued, or cash basis. This is because taxation laws do not allow forecasts and cost savings that can reduce taxable income and tax laws do not allow for management to use commercial accounting estimates or methods in tax reporting (Mills as cited in Wijayanti, 2006).

Temporary Differences results in a shift in recognition of income or expenses from one accounting period to the following accounting period. Saputro (2011) states that some transactions that can cause different time, among others are:

- Income in calculation of tax after accounting profit namely gross profit of installment sales, gross profit of long-term contract, income from stock investment; 
- Cost or tax calculation loss after accounting earnings: estimated warranty cost/product guaranteee, estimated loss of contract from purchasing, inventory, loss of receivables and short-term investment;

- Earning prior to accounting profit: rent, interest and payment;

- Tax expense or loss before accounting profit: depreciation and construction of fixed assets cost (such as tax and interest).

Permanent Differences are items included in one measure of profit, but may not be included in other profit measures. This means that if an item is taken into accounting earnings, it is possible that the item is not included in the fiscal profit and vice versa (Hanlon, 2005). This may occur due to principle difference between commercial accounting and fiscal accounting. The items included in the fixed differences include a) bank interest; b) dividend payout, except dividends from a limited liability company (LLC) having shares in another LLC of $25 \%$ or more, dividend receipts excluding taxabl non-taxable items as stipulated in the Income Tax Law; c) deletion of the sweepstakes prize; d) gains from investments in stock exchanges; e) income in the form of donations from parties having business, employment, ownership and tenure relationships; f) the cost of donations / assistance, in addition to the cost of donations for natural disasters categorized as national disasters; g) the provision of the enterprise to employees in kind and enjoyment shall not be expensed as a cost to calculate the taxable income, unless the grant of the enterprise in the form of money may be expensed as a cost to calculate the taxable income; $h$ ) income tax on royalties borne by the creditor; i) representative fees not included in the normative list; j) the cost of fines and tax interest; k) grants or inheritance; I) other non-nondeductible expenses as set forth in the tax laws.

Company Valueю Company value is performance of a company that is reflected by stock price developed from demand and supply in the capital market which reflects the community's assessment of the company's performance (Harmono, 2009). Company value is an investor's perception of company, which is often associated with stock prices (Brigham, 2012). High stock price results in high company value, and increases market confidence not only to the company's current performance but also on prospects of the company in the future.

Based on this understanding, company value is a representative value owned by the company as a form of public assessment of the company's performance. Company value reflected in the stock price shows level of market confidence in the future prospects of the company. Information published as an announcement will signal investors in making investment decisions. If the announcement contains a positive value, it is expected that the market will react at the time the announcement is received by the market. When the announcement of the information issued contains a good signal for investors, there will be an increase in the volume of stock trading resulting in high stock prices in the capital market as a reflection or the value of the company.

Company value can be measured using a ratio called the market value ratio (Brigham, 2012). The market value ratio is a set of ratios that relate the company's stock price to its earnings, cash flows and book value per share. The ratio provides an indication for management regarding the investor's view of the risks and prospects of the company in the future.

Brigham (2012) explains several approaches on market value ratio analysis:

- Price Earning Ratio (PER), is comparison between stockprice in prime stock market and received income. PER is a function of changes in the ability of the expected profit in the future. The greater the PER, the more likely the company to grow and increase the value of the company.

- Price Book Value (PBV) is ratio showing whether stock price is above or below book value price of the shares. The higher this ratio is, the higher market trust towards prospect of the company is.

- Dividend Yield Ratio is ratio that shows the current rate of income earned from stock investments 
- Dividend Payout Ratio (DPR) is ratio that shows the amount of profit paid to shareholders in the form of dividends.

Company value in this study will be measured by (PBV) to show the company's ability to create a relative value of capital. Price book value (PBV) is a ratio that indicates whether the stock price (market price) is traded above or below the book value of the shares (Brigham, 2012). The ratio of stock price to the book value of the company or PBV, shows the level of ability of the company creates a value relative to the amount of capital invested. Harmono (2009) explains that high PBV reflects the high stock price compared to the book value of the stock. The higher the stock price, the more successful the company creates value for shareholders. The success of the company creates that value of course gives hope to shareholders in the form of bigger profit.

Simply stated that price book value (PBV) is the market ratio used to measure the performance of the stock market price against the value of the book. The higher the PBV means the market believes in the prospect of the company. The researchers use PBV as a measure of the company value with the following reasons:

- Book value refers to relatively stable intuitive measure that can be compared to market price. Investor who does not find metode discounted cash flow reliable can use price book value as comparison.

- Book value provides consistent accounting standard for all companies. PBV can be contrasted between similar companies as guideline for under or overvaluation.

- Companies with negative earning that can be evaluated using price earning ratio (PER) may be evaluated using PBV.

\section{METHODS OF RESEARCH}

The study was explanatory study with quantitative approach. Explanatory research aims at explaining relationship between two or more phenomena or variables, both their direction and degree. The study examines the effect of book tax different as measured by temporary differences and permanent differences to price book value in manufacturing companies categorized as emittent in Indonesian Stock Exchange.

The independent variables were Temporary Differences $\left(X_{1}\right)$ and Permanent Differences $\left(X_{2}\right)$. The dependent variable was price book value $(Y)$. Temporary Differences $\left(X_{1}\right)$ refer to discrepancy between the numbers of assets or liability and the amount of tax a company should pay. Temporary Differences are obtained using the following formula:

$$
\text { TEMP }=\left\{-\frac{\text { deferred tax expense }}{t}\right\} * \frac{1-t}{\text { average assets }}
$$

Weber as cited in Jacson (2009). Permanent Differences $\left(X_{2}\right)$ refer to different treatments towards income and fee in which the income and fee are recognized by commercial accounting but not taxation accounting. Permanent Differences can be obtained using the following formula:

$$
P E R M=T A X^{D I F F}-T E M P
$$

Weber as cited in Jacson (2009). Price Book Value (Y) is ratio between stock price and book value of the company that shows company's ability to create a value relative to the amount of capital invested. Price Book Value can be obtained using the following formula:

$$
\text { PBV }=\frac{\text { Market Price of Each Stock }}{\text { Book Price of Each Stock }} * 100 \%
$$

The data analysis methods used in this research were descriptive statistics and inferential statistics. Descriptive statistics are used to describe generally obtained data. Parametric inferential statistics is used for hypothesis testing includes multiple linear 
regression. The stages of analysis used in this study were descriptive statistics, classical assumption test, multiple linear regression, and hypothesis test using Statistical Package for Social Science (SPSS) version 21.0.

Figure 1 described three hypotheses used in the study.

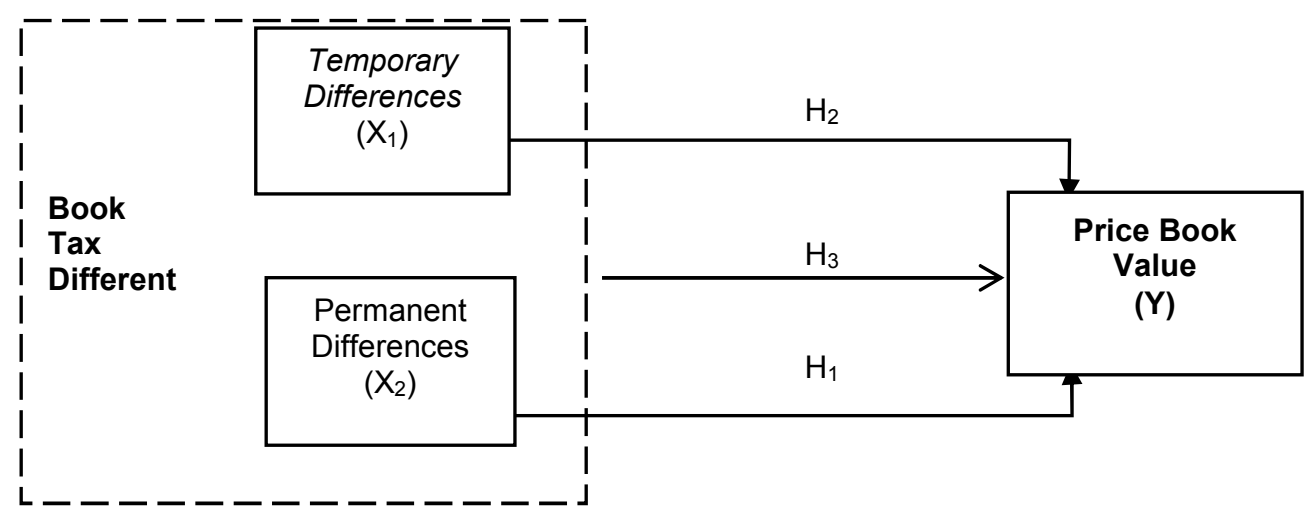

Figure 1 - Hypotheses

Hypothesis 1: temporary difference has influence towards price book value.

Hypothesis 2: permanent difference has influence towards price book value.

Hypothesis 3: temporary differences and permanent differences, as indicators of book tax different, simultaneously have influence towards price book value.

\section{RESULTS AND DISCUSSION}

The objects of the study were companies categorized as consumer goods industry listed in Indonesian Stock Exchange. These data are the financial statements of the research objects between 2012 and 2016.

Multiple Regression Testing Result: partial significance testing (t-test). The objective of partial significance testing using t-test is to identify partial influence of independent variable towards dependent variable. The level of significance is $5 \%$ or 0.05 . Table 1 discussed the result of partial significance testing result of temporary differences and permanent differences influence towards price book value (PBV).

Table 1 - Partial Parameter Significance Test Result $\left(t_{\text {test }}\right)$ Coefficients ${ }^{a}$ from Multiple Linear Regression Model

\begin{tabular}{|c|c|c|c|}
\hline Model & $\mathrm{B}$ & $\mathrm{t}_{\text {value }}$ & Significance \\
\hline (Constant) & 3.497327 & 5.563 & 0.002 \\
\hline $\mathrm{LnX}_{1}$ & -0.068 & -0.468 & 0.644 \\
\hline $\mathrm{LnX}_{2}$ & 0.754 & 3.622 & 0.001 \\
\hline $\mathrm{t}_{\text {table }}$ & \multicolumn{3}{|c|}{2.919986} \\
\hline
\end{tabular}

Source: Data Analysis, 2017.

The testing used basic assumption to determine influence and significant of independent variable that was to identify degree of freedom, evaluate whether or not level of significance was lower than $5 \%(<0.05)$ and compare between $t$-value and critical point based on the table. T-test result of the independent variables, temporary differences and permanent differences towards price book value (PBV) were elaborated as follow:

- The constant was 3.497327 which meant temporary differences and permanent differences may increase price book value (PBV) as many as the constant with assumption that values of all independent score were zero (0).

- Regression coefficient score (B) of temporary differences was-0.068 showing that one point decrease or increase in temporary differences would decrease/increase 
price book value (PBV) score by $0.068 \%$ with assumption that all scores of independent variables did not change. Negative (-) regression coefficient score showed influence of temporary differences towards price book value (PBV) was at the opposite direction. Opposite direction was shown when an increase in temporary differences resulted in decrease in price book value (PBV). Temporary differences has lower $t_{\text {value }}$ than $t_{\text {table }}(-0.468<2.919986)$ and probability of the significance was 0.644 or higher than alpha $(\alpha) 5 \%(0.644>0.05)$. The conclusion was temporary differences did not have significant influence towards price book value (PBV).

- Regression coefficient score (B) of permanent differences was 0.754 showing that one point decrease or increase in permanent differences would decrease/increase price book value (PBV) score by $0.754 \%$ with assumption that all scores of independent variables did not change. Psoitive (-) regression coefficient score showed influence of permanent differences towards price book value (PBV) was at the same direction. It meant increasing permanent differeces would increase price book value (PBV). Permanent differences had higher $t_{\text {value }}$ than $t_{\text {table }}(3.622>$

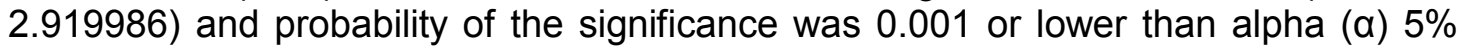
$(0.001<0.05)$. The conclusion was permanent differences had positive and significant influence towards price book value (PBV).

Multiple Regression Test: simultaneous significance testing result (F-test). The objective of simultaneous significance test using F-test is to identify simultaneous significance of independent variables towards dependent variable. The level of significance was $5 \%$ or 0.05 . Table 2 described the result of the simultaneous significance testing result (F-test) of temporary differences and permanent differences influence towards price book value (PBV).

Table 2 - Simultaneous Significant Test Result (F-test) ANOVA ${ }^{a}$ from Multiple Linear Regression Model and $F_{\text {table }}$

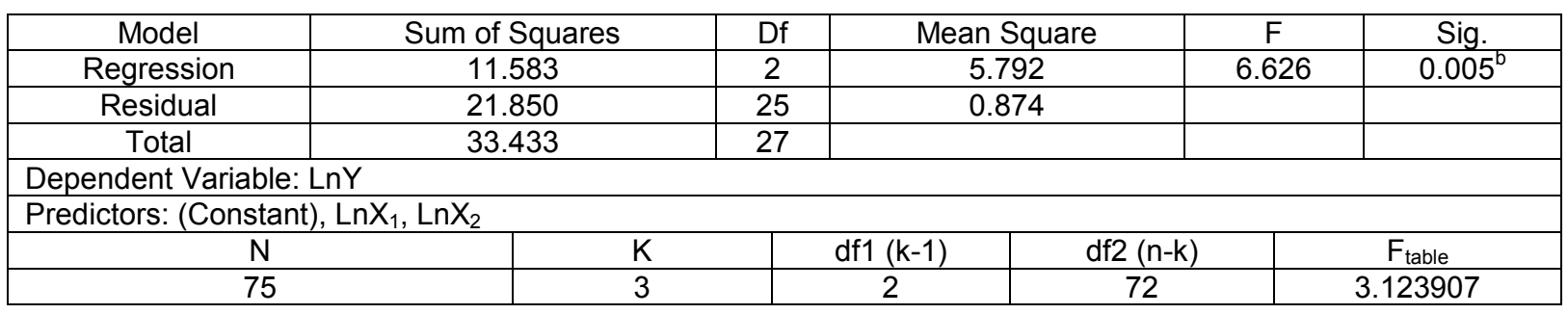

Source: Data Analysis, 2017.

Based on Table 2, F-test with ANOVA ${ }^{a}$ showed that $F_{\text {value }}$ was 6.626 , with $F_{\text {table }}$ 3,123907 or $F_{\text {value }}$ was higher than $F_{\text {table }}(6.626>3.123907)$. In other words, the independent variables, temporary differences and permanent differences simultaneously had significant influence towards the dependent variable, price book value (PBV). Another evidence was the level of significance (probability) was 0.005 or lower than alpha $0.05(0.005<0.05)$. In conclusion, using multiple linear regression, the second hypothesis $\left(\mathrm{H}_{2}\right)$ was accepted.

Coefficient Determination $\left(R^{2}\right)$ Analysis Resul. $\mathrm{R}^{2}$ testing aims at identifying how much ability model has to explain dependent variable variance and how accurate regression model is. The lower $R^{2}$ was or the closer it is to 0 , independent variable ability to explain dependent variable is strictly limited. Table 3 explained the result of $R^{2}$ test.

Table $3-R^{2}$ Test

\begin{tabular}{|c|c|c|}
\hline $\mathrm{R}$ & $\mathrm{R}$ Square & Adjusted R Square \\
\hline $0.589^{\mathrm{a}}$ & 0.346 & 0.294 \\
\hline
\end{tabular}

Source: Data Analysis, 2017.

Based on Table 3 Adjusted $\mathrm{R}^{2}$ score was 0.294 . It meant $29.4 \%$ variance of price book value may be explained by variance of temporary differences and permanent differences. On 
the other hand, the remaining $70.6 \%$ was explained by other variables outside the study. Besides the coefficient determination, it also revealed correlational coefficient showing relationship between independent variable, book tax different, measured using temporary differences and permanent differences and price book value. $\mathrm{R}$ (correlational coefficient) score was 0.589 . The score showed relationship between independent variable, book tax different, measured using temporary differences and permanent differences and price book value was categorized as average because the score was between 0.4 and 0.6.

Interpretation. The study described influence of book tax value measured using temporary differences and permanent differences towards price book value.

Table 4 - Summary of the Findings

\begin{tabular}{|c|c|c|c|c|c|c|c|}
\hline \multirow{2}{*}{ Hypothesis } & \multicolumn{2}{|c|}{$\mathrm{t}$-test } & \multicolumn{2}{c|}{ F-test } & \multicolumn{2}{c|}{$\begin{array}{c}\text { Determination } \\
\text { Coefficient }\end{array}$} & \multirow{2}{*}{ Information } \\
\cline { 2 - 7 } & $\mathrm{t}_{\text {value }}$ & $\mathrm{t}_{\text {table }}$ & $\mathrm{F}_{\text {value }}$ & $\mathrm{F}_{\text {table }}$ & $\mathrm{R}$ & $\mathrm{R}^{2}$ & \\
\hline $\begin{array}{c}\mathrm{H}_{1} \text { : temporary differences ==> } \\
\text { price book value }\end{array}$ & -0.468 & 2.919986 & & & & & Rejected \\
\hline $\begin{array}{c}\mathrm{H}_{2} \text { : permanent differences =-> } \\
\text { price book value }\end{array}$ & 3.622 & 2.919986 & & & & & Accepted \\
\hline $\begin{array}{c}\mathrm{H}_{3}: \text { temporary differences \& } \\
\text { permanent differences ==> price } \\
\text { book value }\end{array}$ & & & 6.626 & 3.123907 & 0.589 & 0.294 & Accepted \\
\hline
\end{tabular}

Based on Table 4, $\mathrm{H}_{1}$ was rejected which meant temporary differences did not have significance influence towards price book value. A change in temporary differences was not determining or inhibiting factor explaining change in price book value significantly. Tang and Firth (2012) elaborated that temporary differences are situations that occur due to differences in the time of income recognition or the cost of taxes and accounting, resulting in higher accounting profits than tax income or otherwise in a period. It can be concluded that the difference is only temporary and in some combined periods the difference will be the same in the final calculation, so this does not affect the value of the company as measured by the price book value significantly. The findings of this study are in line with Coprix, et.al (2011) which states that temporary differences do not have significant influence on the difference of investor opinion reflecting the value of the stock of the company. Another study related to this study is one conducted by Donohoe and McGill (2011) which states temporary differences do not have any influence towards market response. Although the two related studies do not use price book value as dependent variable, they are still related to using market responses and investor opinions as a reflection of company value.

The findings of this study indicate possibility of deferred tax burden in the consumer goods industry is zero or the company has the remainder of the previous year's tax payments recorded on the deferred tax benefit account. In addition, the average amount of assets used as a deferred tax burden on each company is not equal or congruent, thus not being able to contribute significantly to the formation of the value of temporary differences. Another indication that arises is the transaction resulting in deferred tax benefits.

Some of the transactions that may result in deferred tax benefits include cost or loss of tax calculation after accounting income which includes estimated cost of product warranty, estimated loss of contract purchase, and loss of receivables and short-term investments. This happens because companies in the consumer goods industry produce goods continuously, and thus, such transactions are temporary until there is some adjustment in corporate accounting.

$\mathrm{H}_{2}$ was accepted that meant permanent differences have significant influence towards price book value of the companies categorized as consumer goods industry. It means a change in calculating permanent differences becomes one of determining or inhibiting factors explaining change in price book value. The findings show that increasing permanent differences will result in increasing price book value.

The findings of this study are not in accordance to Donohoe and McGill (2011)'s which states that companies with large permanent differences are significantly negative towards the 
market response and manager behavior in anticipation of it. Although the study did not use price book value as a measure of corporate value, the market response can be used as a benchmark in determining corporate value. Different findings between Donohoe and McGill (2011)'s and this study happens due to the dependent variable. This study indicated that permanent differences had positive effect while Donohoe and McGill showed it had negative effect. The findings of this study are in line with Comprix, et.al (2011)'s which states that permanent differences have a positive effect on different investor's opinion that reflects stock price of the company.

Hanlon (2005) stated that permanent differences are items included in one profit measure, but not included in other profit measures. This means that if an item is taken into account in accounting earnings, it is possible that the item is not included in the size of the fiscal profit and vice versa (Hanlon, 2005). This may occur due to the principle difference between commercial accounting and fiscal accounting. This raises the difference between profit and loss post and taxable income on the company's financial statements as well as fiscal disbursement reports.

The relationship between permanent differences to price book value that went to the same direction indicated investors may prefer companies with higher permanent differences because it was more real in delivering the company's financial statements. This was possible because the component of the calculation of price book value was the share price divided by the book value per share, which meant the price book value may indicate the investor's response to the company. In addition, the magnitude of the value of permanent differences was also inseparable from the amount of book tax differences reduced by temporary differences with the forming components such as taxable income, net income, deferred tax expense and average assets. Based on these calculations, it is possible that companies with higher permanent differences are considered more real in reporting their financial statements.

$\mathrm{H}_{3}$ was accepted which meant temporary differences and permanent differences, the indicators of book tax value, simultaneously had significant influence towards price book value of companies categorized as consumer goods industry. Simultaneous significance test result ( $F$-test) with ANOVA ${ }^{a}$ showed $F_{\text {value }}$ was 6.626 , while $F_{\text {table }}$ was 3.123907 or $F_{\text {value }}$ was higher than $F_{\text {table }}(6.626>3.123907)$. Another evidence was level of significance (probability) was 0.005 or lower than alpha $0.05(0.005<0.05)$. It means a change in temporary differences and permanent differences scores simultaneously are one of determining factors to explain a change in price book value score. It is in line with Comprix, et.al (2011) that temporary differences and permanent differences have significant influence towards market response on stock demand.

Another study on the influence of book tax differences towards company value was Donohoe and McGill (2011). It stated that book tax differences variables had significant influence towards company value which was reflected in market response. Despite using different variables of company value, the findings of the study are the same as Comprix, et al (2011)'s as well as Donohoe and McGill (2011)'s that is simultaneously temporary differences and permanent differences have significant influence towards company value.

Substantive evidence in which temporary differences and permanent differences simultaneously had significant influence towards price book value shows the findings of the study are consistent to the previous studies and they are not the opposite of Lev and Nissim (2004) as cited in Comprix, et.al (2011). Liv and Nissim as cited in Comprix, et.al (2011) state that there is positive correlation between level of book tax differences and stock return. In this context, stock return describes investors' response in making predictions about the profit opportunities that will be obtained when deciding to invest in a company through capital market.

In this regard, investors may consider the correlation between fiscal profit information (taxable income) and company value before making a quality investment decision in the future. Discussion on fiscal profit will not be separated from the concept of book tax differences since in looking for fiscal profit one should first correct the components of temporary differences and permanent differences that are still contained in accounting profit. 


\section{CONCLUSION}

Temporary differences do not have significant influence towards price book value. It means temporary differences are able to be supporting or inhibiting factor of price book value in really small percentage or not significant.

Permanent differences do not have significant influence towards price book value. It means permanent differences are able to become supporting factor in describing price book value level of company. Increasing permanent differences will increase price book value.

Temporary differences and permanent differences as main indicators of book tax different have positive, simultaneous and significant influence towards price book value of companies in consumer goods industry. It means temporary differences and permanent differences simultaneously are determining factors in describing price book value level of company. Increasing temporary differences and permanent differences simultaneously will result in increasing price book value.

\section{REFERENCES}

1. Bamberg, P. D. G. \& Spremann, P. D. K. (1989). Agency Theory, Information, and Incentives. second edition. verlag berlin. springer. 10.1007/978-3-642-75060-1

2. Brigham, E.F. (2012). Dasar-dasar Manajemen Keuangan, Buku 1. Jakarta: S. Empat.

3. Comprix, Joseph. Jared A. Moore and Roger Graham. (2011). Empirical Evidence On the Impact of Book-Tax Differences On Divergence of Opinion Among Investors, Journal of Accounting and Economics.

4. Deviana, B. S. (2010). Kemampuan Beban Pajak Tangguhan and Beban Pajak Kini dalam Mendeteksi Manajemen Laba Pada Saat Seasoned Equity Offereings. Semarang: Universitas Diponegoro.

5. Donohoe, M.P. (2011). Effects of Increased Book-Tax Difference Tax Return Disclosures on Firm Valuation and Behavior, American Accounting Association, 33: 35-65.

6. Ghozali, I. (2013). Aplikasi Analisis Multivariat dengan Program IBM SPSS 21 Update PLS Regresi. Semarang: Penerbit Universitas Diponegoro.

7. Hanlon, M. (2005). The Persistence of Earnings, Accruals, and Cash Flows When Firms Have Large Book-tax Differences, The Accounting Review 80, Issue Working Paper SSRN, 137-166.

8. Harmono, (2009). Manajemen Keuangan Berbasis Balanced Scorecard Pendekatan Teori, Kasus and Riset Bisnis. Jakarta: Bumi Aksara.

9. Ikatan Akuntan Indonesia (2007). Standar Akuntansi Keuangan. Jakarta: Salemba Empat.

10. Jackson, M. (2009). Book Tax Differences and Earning Growth. Oregon: University of Oregon.

11. Jensen, M. C. \& Meckling, W. H. (1976). Theory of the firm: Managerial behavior, agency costs and ownership structure, Journal of Financial Economics, October, 3(4), 305-360.

12. Kementerian Perindustrian Republik Indonesia. (2015). Media Industri. Paket Kebijakan Dorong Pertumbuhan Ekonomi, 1 December, 44-25.

13. Saputro, N. A. (2011). Pengaruh Book Tax Differences Terhadap Pertumbuhan Laba. Semarang: Universitas Diponegoro.

14. Tang, T. Y. \& Firth, M. (2012). Earnings Persistence and Stock Market Reactions to the Different Information in Book-Tax Differences: Evidence From China. The International Journal of Accounting, Volume 47, 369-397.

15. Trisyanti. (2009). Analisis Pengaruh Karakteristik Perusahaan and Karakteristik Kepemilikan Saham terhadap Initial Retun pada Perusahaan yang Melakukan IPO di BEl. Lampung: Universitas Lampung

16. Wijayanti, H. T. (2006). Analisis Pengaruh Perbedaan antara Laba Akuntansi and Laba Fiskal terhadap Persistensi Laba, Akrual, and Arus Kas. Padang: Simposium Nasional Akuntansi IX.

17. Zain, M. (2007). Manajemen Perpajakan, Third Edition. Jakarta: Salemba Empat. 